\title{
PENGEMBANGAN CUSTOMER RELATIONSHIP MANAGEMENT BERBASIS SISTEM E-COMMERCE
}

\author{
Sugiarto Montana; Muwasiq Mochamad Noor \\ Jurusan Teknik Informatika, Fakultas Ilmu Komputer, Bina Nusantara University \\ Jurusan Magister Teknik Informatika, Fakultas Ilmu Komputer, Bina Nusantara University \\ Jln. K.H. Syahdan No.9, Palmerah, Jakarta Barat 11480 \\ muwasiq@edi-indonesia.co.id
}

\begin{abstract}
PT Dwisanjaya Abadi Mukti is a company engaged in distributing Pertamina lubricating agent with products for industrial and automotive lubricants. Therefore, companies need a Customer Relationship Management E-commerce-based systems, to address the issues of purchasing and service to customers that are still conducted manually. Systems analysis is done through observation interviews, and literature; analysis of survey findings; and identification of information needs from survey. The system is designed to give advantage to the user as to obtain the desired information quickly, to acquire new customers, improve customer relationships, and retain customers; other than that for the company this system reduces operating costs, more efficient time, accessible anytime and anywhere, improving work productivity, increase sales, increase the number of customers, and improve customer satisfaction.
\end{abstract}

Keywords: customer relationship management, e-commerce, front end, back end

\section{ABSTRAK}

PT. Dwisanjaya Abadi Mukti adalah sebuah perusahaan yang bergerak di bidang agen pelumas pertamina dengan produk pelumas untuk industri dan otomotif. Oleh karena itu, perusahaan membutuhkan Customer Relationship Management berbasis sistem E-commerce, untuk mengatasi persoalan pembelian dan pelayanan kepada pelanggan yang masih manual. Analisis sistem dilakukan melalui observasi wawancara, dan studi pustaka; analisis terhadap temuan survey; dan identifikasi kebutuhan informasi dari hasil survey. Sistem yang dirancang memberi keuntungan bagi pengguna seperti memperoleh informasi yang diinginkan dengan cepat, untuk memperoleh pelanggan baru, meningkatkan hubungan dengan pelanggan, dan mempertahankan pelanggan; selain itu bagi perusahaan sistem ini mengurangi biaya operasional, waktu jadi efisien, dapat diakses kapanpun dan dimanapun, meningkatkan produktivitas kerja, meningkatkan penjualan, meningkatkan jumlah pelanggan, meningkatkan kepuasan pelanggan

Kata kunci: customer relationship management, e-commerce, front end, back end

\section{PENDAHULUAN}

\section{Latar Belakang}

Dewasa ini persaingan dalam dunia bisnis semakin cepat dan mendorong masing-masing perusahaan untuk selalu berkembang dan beradaptasi dengan perubahan untuk dapat memenangkan persaingan tersebut. Perkembangan teknologi informasi yang sangat pesat telah banyak merubah kegiatan bisnis yaitu perubahan ke arah bisnis yang berbasis internet. Dengan didorong oleh kebutuhan akan peningkatan kinerja serta penghematan waktu dan biaya, maka internet menjadi salah satu media komunikasi yang penting dalam memenuhi kebutuhan tersebut, khususnya dalam menjalankan bisnis. Penerapan praktis dari teknologi internet pada dunia bisnis saat ini sudah semakin berkembang yakni berdagang di dunia maya dengan memanfaatkan internet yang kerap disebut dengan e-commerce (electronic commerce).

Penerapan e-commerce dapat merubah kebiasaan pelanggan yang awalnya memesan dan membeli secara konvensional menjadi secara online. Waktu dan jarak tidak lagi menjadi masalah dalam bertransaksi, karena melalui internet pelanggan mendapatkan informasi tentang produk yang diinginkan bahkan melakukan transaksi kapanpun dan di mana pun. Sehingga perusahaan dapat memperluas jaringan pemasaran dan penjualannya, mencapai keunggulan kompetitif dan meningkatkan keuntungan.

Pemenuhan kebutuhan konsumen pun berubah dengan diterapkannya e-commerce, kunci keberhasilan perusahaan bukan hanya terletak pada kualitas produk/ jasa, tetapi seberapa jauh upaya perusahaan memuaskan kebutuhan pelanggannya kemudian memberikan pelayanan yang baik dan menyenangkan mereka untuk memastikan mereka menjadi pelanggan setia. Perusahaan harus mampu menyediakan layanan yang mudah diakses, mudah digunakan, dan sederhana namun tetap dapat menjadi media pemasaran sekaligus membantu pelanggan dalam melakukan transaksi. Cara suatu perusahaan berinteraksi dengan pelanggan pun berubah, perusahaan makin menyadari bahwa memahami pelanggan, merespon kebutuhan pelanggan dengan cepat dan tepat menjadi sesuatu yang penting bagi bisnis mereka. Untuk memperoleh itu semua, setiap perusahaan perlu mengenali pelanggannya serta bersifat proaktif dan antisipatif terhadap keinginan pelanggan.

Customer Relationship Management (CRM) adalah strategi tingkat korporasi, yang berfokus pada pembangunan 
dan pemeliharaan hubungan dengan pelanggan yang memungkinkan terciptanya kesetiaan pelanggan bukan hanya pada produknya namun juga setia terhadap perusahaan. Penerapan strategi Customer Relationship Management dapat dikembangkan untuk memperoleh pelanggan baru (acquire), meningkatkan hubungan dengan pelanggan (enhance), dan mempertahankan pelanggan (retain) yang berujung pada terciptanya kesetiaan pelanggan. Customer Relationship Management berbasis sistem e-commerce dijadikan sarana untuk meningkatkan kepuasan pelanggan dalam usaha meningkatkan penjualan.

PT Dwisanjaya Abadi Mukti merupakan perusahaan agen resmi pelumas Pertamina, menyadari bahwa persaingan bisnisnya semakin ketat setelah dikeluarkannya ijin masuk bagi pelumas import dari Ditjen Migas pada tahun 2002, untuk memberikan kemudahan untuk membuat merek pelumas baru, hal ini menyebabkan merek pelumas baru bermunculan dengan membawa wajah pemain baru. Saat ini terdapat kurang lebih 200 merek pelumas yang beredar di pangsa pasar bisnis pelumas Indonesia. Dengan tingkat persaingan di dunia bisnis pelumas Indonesia yang amat ketat. Apalagi saat ini tingkat keuntungan bersih yang didapat dari pasar semakin tipis maka perusahaan harus mengetahui cara mempertahankan usahanya agar tetap exist di bisnis pelumas ini. Agen resmi pelumas Pertamina sebagai ujung tombak pemasaran, pendistribusian, penjualan, promosi juga dihadapkan untuk selalu siap dan melakukan inovasi baik dalam manajemen (kepengurusan), pemasaran dan penjualan maupun pelayanan pelanggan.

Dalam kondisi persaingan yang ketat hal utama yang harus diprioritaskan oleh PT Dwisanjaya Abadi Mukti sebagai agen pelumas adalah kepuasan pelanggan agar dapat bertahan, bersaing, dan meningkatkan penjualan serta adanya suatu media untuk dapat memperluas pemasarannya. PT Dwisanjaya Abadi Mukti bermaksud ingin memberikan pelayanan yang lebih mudah dan lebih praktis untuk konsumen sehingga dapat meningkatkan penjualan dan meningkatkan persaingan. Hal ini mendorong PT Dwisanjaya Abadi Mukti untuk mengembangkan sistem penjualan berbasiskan teknologi. Dengan adanya penjualan berbasis internet maka diharapkan pelanggan akan semakin puas dengan layanan sistem pembelian produk melalui internet dan diharapkan penjualan mengalami peningkatan. Dengan Pengembangan Customer Relationship Management berbasis sistem E-commerce untuk pelanggannya, PT. Dwisanjaya Abadi Mukti mengharapkan nilai tambah dalam model bisnisnya yang akan memperkuat nilai kompetitif perusahaan.

Atas dasar pemikiran tersebut, penulis ingin membuat pengembangan Customer Relationship Management berbasis sisteme-commerce, yang dapat digunakan olehPT. Dwisanjaya Abadi Mukti untuk membantu melakukan aktifitas bisnisnya. Dengan begitu diharapkan PT Dwisanjaya Abadi Mukti dapat melayani pangsa pasar yang luas dan mampu memberikan pelayanan yang memudahkan pelanggannya dalam berbelanja dalam usaha meningkatkan penjualan pelumas pertamina.

\section{Identifikasi Masalah}

Setelah melihat sistem yang ada dan melalui wawancara maka didapat masalah yang dihadapi oleh PT Dwisanjaya Abadi Mukti adalah: (1) kesulitan pelanggan untuk memesan barang diluar jam operator perusahaan, karena keterbatasan perusahaan dalam melayani pelanggan secara real time 24 jam sehari ataupun tujuh hari seminggu; (2) membutuhkan banyak karyawan untuk melayani pelanggan dalam telepon ataupun langsung datang ke perusahaan; (3) membutuhkan banyak kertas untuk brosur produk pelumas; (4) membutuhkan biaya yang besar untuk salesman untuk penjualan dan promosi; (5) membutuhkan biaya telepon yang besar dan waktu yang lama untuk menjelaskan produk dan melakukan pembelian; (6) kesulitan dalam pencarian data misalnya untuk mencari histori transaksi pembelian pelanggan; (7) kurangnya keamanan data, karena pencatatan masih disimpan dalam buku-buku maka karyawan lain dapat melihat data secara bebas, sehingga kemungkinan terjadinya kebocoran data sangat besar; (8) kemungkinan kehilangan data, jika terjadi hal-hal diluar dugaan seperti kebakaran, banjir, kerusuhan tentunya resiko kehilangan data bagi perusahaan sangat besar; (9) pelanggan untuk bertanya dan memberikan saran dengan menggunakan telepon, itu membutuhkan biaya telepon dan waktu; (10) pelanggan untuk menjawab pertanyaan yang diajukan sebagai feedback bagi perusahaan dengan kuisioner membutuhkan kertas, kuisioner diberikan ke pelanggan membutuhkan waktu dan biaya kirim untuk kirim kertas kuisioner; (11) mengetahui kecenderungan permintaan dari pelanggan terhadap suatu produk tertentu dengan menggunakan telepon, membutuhkan biaya telepon, waktu dan mencatat di kertas secara manual; (12) pertanyaan dan jawaban yang sering ditanyakan oleh pelanggan, setiap pelanggan menanyakan melalui telepon membutuhkan waktu karyawan untuk melayani pelanggan; (13) mengurangi pembuatan laporan secara manual.

\section{Ruang Lingkup}

Ruang Lingkup pekerjaan thesis ini terletak pada pengembangan Customer Relationship Management berbasis sistem e-commerce pada PT Dwisanjaya Abadi Mukti. Pengembangan Customer Relationship Management berbasis sistem e-commerce melalui website yang dibangun mencakup jenis Customer Relationship Management yang bersifat operational dan sebagian kecil collaborative serta sebagian kecil analytical sebagai pemenuhan standar untuk konsep Customer Relationship Management dan dijalankan dalam e-Commerce sebagai solusi pemecahan permasalahan perusahaan. Ruang lingkup dari thesis ini adalah: proses pembelian produk pelumas, proses melihat histori pembelian, proses memberi pemberitahuan ke pelanggan, proses untuk bertanya dan memberi saran dari pelanggan, proses menampilkan pertanyaan dan jawaban yang sering ditanyakan, proses untuk menjawab pertanyaan-pertanyaan yang diajukan untuk sebagai feedback bagi perusahaan, dan proses untuk mengetahui persentase kecenderungan permintaan dari pelanggan terhadap suatu masalah tertentu.

\section{Tujuan dan Manfaat}

\section{Tujuan}

Membangun Customer Relationship Management berbasis sistem e-commerce melalui website, antara lain: (1) mengembangkan Customer Relationship Management berbasis sistem E-commerce yang terbagi dua bagian yaitu front office dan back office, untuk mengatasi persoalan pembelian dan pelayanan kepada pelanggan yang masih manual; (2) memperoleh pelanggan baru; (3) meningkatkan hubungan dengan pelanggan; (4) mempertahankan pelanggan; (5) menciptakan wadah interaksi antara pelanggan dan perusahaan melalui website.

\section{Manfaat}

Dengan pengembangan Customer Relationship Management berbasis sistem e-commerce melalui website ini, diharapkan akan bermanfaat bagi perusahaan, antara lain: (1) memberi kemudahan bagi pelanggan dalam berinteraksi denganperusahaandanmemperolehinformasiyangdibutuhkan dengan cepat dan mudah; (2) perusahaan dapat membangun hubungan yang baik dengan pelanggan dan memberikan pelayanan yang baik seperti penanganan saran dan keluhan dengan cepat; (3) perusahaan dapat menjaga loyalitas dengan pelanggan yang telah ada dan dapat menarik pelanggan baru; (4) keluhan pelanggan dapat direspon perusahaan dengan cepat; (5) meningkatkan efisiensi dalam pengelolahan data 
dan menghasilkan efektifitas dari pengelolahan data tersebut; (6) memberi kemudahan dan memperlancar proses transaksi secara akurat sehingga meningkatkan mutu layanan; (7) pelanggan dapat memesan barang diluar jam operator perusahaan, karena keterbatasan perusahaan dalam melayani pelanggan secara real time 24 jam sehari ataupun tujuh hari seminggu; (8) mengurangi biaya pemasaran, penjualan, pelayanan; (9) meningkatkan pendapatan penjualan; (10) meningkatkan efisiensi operasional; (11) dapat menampilkan warning.

\section{Tinjauan Teori}

\section{Kepuasan Pelanggan}

Menurut Irawan (2002), kepuasan pelanggan bukanlah konsep yang baru. Sampai hari ini, kepuasan pelanggan masih merupkan konsep yang sangat relevan. Logika sederhana dari para perilaku bisnis adalah bahwa apabila pelanggan puas, pasti akan terjadi sesuatu yang lebih baik untuk bisnis mereka di masa yang akan datang. Kepuasan pelanggan akan mempengaruhi kinerja keuangan setiap perusahaan.

Pelanggan yang merasa puas adalah pelanggan yang mendapat nilai berharga dari produsen atau penyedia jasa. Pelanggan yang puas akan berbagi kepuasan dengan produsen atau penyedia jasa tersebut. Bahkan pelanggan yang puas akan berbagi rasa dan pengalaman dengan pelanggan lain. Ini akan menjadi referensi bagi perusahaan yang bersangkutan. Oleh karena itu, bagi pelanggan maupun produsen akan sama - sama diuntungkan bila kepuasan pelanggan dapat tercapai.

\section{Definisi Kepuasan Pelanggan}

Satisfaction adalah kata dari bahasa latin, yaitu satis artinya enough atau cukup dan facere yang berarti to do atau melakukan. Jadi, produk ada jasa yang bisa memuaskan adalah produk dan jasa yang sanggup memberikan sesuatu yang dicari oleh pelanggan sampai pada tingkat cukup. Definisi kepuasan Pelanggan menurut Kotler \& Keller (2006) adalah: "A person's feeling of pleasure or dissapointment resulting from comparing a product's perceived performance (or outcome) in relation to his or her expectation" (p. 136).

Bila kinerja kecil dari yang diharapkan, maka pelanggan akan kecewa dan tidak puas. Bila kinerja sama dengan harapan maka pelanggan akan puas dan bila kinerja melebihi harapan, maka pelanggan akan sangat puas. Kepuasan pelanggan ditentukan oleh persepsi pelanggan atas performansi produk atau jasa dalam memenuhi harapan pelanggan. Pelanggan akan merasa puas bila harapannya terpenuhi. Faktor pendorong kepuasan pelanggan menurut Handi Irawan terbagi dalam lima poin utama, yaitu kualitas produk, harga, kualitas pelayanan, dan faktor emosional.

\section{Kualitas Produk}

Pelanggan puas kalau setelah membeli dan menggunakan produk, ternyata kualitas produknya baik. Kualitas produk adalah dimensi global dan yang paling tidak ada enam elemen, yaitu: performance, durability, feature, reliability, consistency, dan design.

\section{Harga}

Untuk pelanggan yang sensitif, biasanya harga murah adalah sumber kepuasan paling penting karena mereka akan mendapatkan value for money yang tinggi.

\section{Kualitas Pelayanan}

Kualitas pelayanan bergantung pada tiga hal, sistem, teknologi, dan manusia. Faktor manusia memegang peranan $70 \%$. Tidak mengherankan, kepuasan terhadap kualitas pelayanan biasanya sulit ditiru. Salah satu konsep kualitas pelayanan adalah SerQual. Berdasarkan konsep ini, kualitas pelayanan diyakini mempunyai lima dimensi yaitu : reliability, responsiveness, assurance, emphathy, dan tangible.

\section{Faktor Emosional}

Driver ini relative penting untuk beberapa produk yang berhubungan dengan gaya hidup seperti mobil, kosmetik, dan pakaian. Rasa bangga, percaya diri, simbol sukses, bagian dari kelompok orang penting dan sebagainya adalah contoh - contoh nilai emosional yang mendasari kepuasan pelanggan. Biaya dan kemudahan untuk mendapat produk dan jasa. Pelanggan akan semakin puas apabila relative mudah, nyaman, dan efisien dalam mendapat produk atau pelayanan.

\section{Persepsi Pelanggan}

Persepsi didefinisikan sebagai proses dimana individu memilih, mengorgnisasikan, serta mengartikan stimulus yang diterima melalui alat inderanya menjadi suatu makna. Meskipun demikian, makna dari proses persepsi juga dipengaruhi oleh pengalaman masa lalu individu yang bersangkutan (Rangkuti, 2002). Persepsi pelanggan terhadap produk jasa berpengaruh terhadap tingkat kepuasan pelanggan, kepuasan pelanggan, dan nilai pelanggan.

\section{Hubungan Kepuasan Pelanggan dengan Perilaku Pelanggan}

Beberapa tipe pelanggan yang dapat diidentifikasi dari menghubungkan tingkat kepuasan pelanggan dengan perilaku pelanggan (Schiffman, 2005), yaitu: (1) para pelanggan yang sangat puas adalah salah satu dari, pelanggan setia(loyalist) yang memelihara pembelian, atau para apostles yang memiliki pengalaman-pengalaman melebihi harapan mereka dan memberikan hal yang sangat positif mengenai perusahaan pada yang lain; (2) defectors adalah pelanggan yang merasa netral atau hanya cukup puas dan mungkin berhenti melakukan bisnis dengan perusahaan; (3) terrorist yang mempunyai pengalaman negatif dengan perusahaan, dan menyebarkan hal yang negatif tersebut; (4) hostages adalah pelanggan yang tidak berbahagia; (5) mercenaries adalah pelanggan yang sangat puas tetapi tidak memiliki kesetiaan pada perusahaan dan mungkin beralih karena dorongan harga yang lebih murah di tempat lain, menentang kepuasan dasar pemikiran kesetiaan.

Para peneliti mengusulkan agar perusahaan bekerja keras untuk mendapatkan pelanggan loyalist, menambah kepuasan pelanggan defectors dan merubahnya menjadi loyalist. Menghindari memiliki pelanggan terrorist dan hostages, serta mengurangi banyaknya pelanggan mercenaries.

\section{Hubungan Kepuasan Pelanggan dengan Loyalitas Pelanggan}

Menurut Kotler \& Keller (2006), kaitan antara kepuasan pelanggan dan loyalitas pelanggan, bagaimanaun tidak sepadan. Yang dapat dijelaskan dari skala 1 sampai 5. Tingkat kepuasan pelanggan yang sangat rendah (level 1), para pelanggan mungkin akan meninggalkan perusahaan dan bahkan berkata jelek. Pada level 2 hingga 4, para pelanggan agak puas tetapi masih menemukan perkataan jelek dan beralih bila tawaran lebih baik datang. Pada level 5, pelanggan sangat mungkin membeli kembali dan bahkan menyebarkan berita 
yang baik dari mulut ke mulut tentang perusahaan. Kepuasan tinggi atau sangat puas menciptakan ikatan emosional dengan merek atau perusahaan, bukan hanya pilihan rasional.

MenurutRangkuti(2002). Dampak kepuasan pelanggan terhadap kesetian dan loyalitas pelanggan berbeda- beda untuk setiap perusahaan. Pelanggan yang loyal belum tentu puas, tetapi sebaliknya pelanggan yang puas cenderung pelanggan yang loyal. Irawan (2002) menyatakan pelanggan yang puas cenderung loyal. Tingkat loyalitas inilah yang sesungguhnya bertanggung jawab terhadap tingkat profitabilitas. Pelanggan loyal juga cenderung tidak sensitif terhadap harga. Oleh karena itu, perusahaan akan memperoleh margin yang lebih baik. Dengan memiliki pelanggan loyal maka iklan dan program promosi menjadi lebih efisien. Pelanggan loyal juga melakukan world of mouth yang positif.

\section{E-commerce}

\section{Pengertian $E$-commerce}

Menurut Chaffey (2002), e-commerce sering kali mengacu kepada kegiatan menjual dan membeli melalui internet, tapi e-commerce mencakup lebih banyak dari sekedar peralatan elektronik untuk transaksi finansial antar perusahaan dengan pelanggannya. E-commerce bukan hanya mencakup pemasaran,pembelian dan penjualan melalui internet, tetapi juga meningkatkan kinerja bisnis melalui konektivitas utuk meningkatkan pelayanan dan mengurangi biaya, serta membuka jalur baru dan persaingan baru.

\section{Karakteristik E-commerce}

Menurut Rayport \& Jaworsky (2004), sesuatu dapat dikatan sebagai e-commerce jika memiliki karakteristik, yaitu: (1) merupakan pertukaran informasi dengan digitalisasi; (2) dimungkinkan karena teknologi; (3) dimediasi oleh teknologi; (4) didalamnya termasuk aktivitas intraorganisasi maupun interorganisasi berbasis teknologi yang mendukung pertukaran tersebut.

Menurut Chaudhury \& Kuilboer (2002), e-commerce mempunyai dua ciri khas yaitu: terkait dengan aktifitas bisnis dan komersial dan sistem dijalankan pada platform internet dan menggunakan World Wide Web.

\section{Customer Relationship Management (CRM)}

\section{Pengertian Customer Relationship Management (CRM)}

Menurut Wijaya \& Darudianto (2009), Customer Relationship Management (CRM) adalah strategi yang digunakan dalam mempelajari kebutuhan dan perilaku pelanggan untuk membangun relasi yang kuat dengan pelanggan. CRM merupakan sebuah pendekatan untuk mengerti dan mempengaruhi tingkah laku pelanggan, yang dapat dilakukan melalui kemampuan berkomunikasi dalam meningkatkan pelayanan terhadap permintaan order pelanggan. Program CRM merupakan suatu proses interaksi pelanggan dengan sistem, dimana pelanggan dapat memperoleh informasi berguna seperti: status order, kontak person in charge, yang akhirnya bertujuan untuk dapat meningkatkan hubungan baik dengan pelanggan. Secara umum, solusi CRM adalah penyediaan informasi yang dibutuhkan untuk mendukung program penjualan, pelayanan dan pemasaran.

Menurut Mane, Desikan \& Srivastava (2005), Customer Relationship Management merupakan strategi dalam mempelajari kebutuhan pelanggan dan memahami perilakunya, untuk membangun relasi yang lebih kuat dan meningkatkan loyalitas pelanggan dan perilaku pembelian.
Ide dari CRM adalah untuk membantu bisnis dalam menggunakan teknologi dan sumber daya manusia untuk memperoleh pengetahuan mengenai perilaku pelanggan dan nilai pelanggan. CRM termasuk semua pengukuran metode untuk pemasaran, integrasi sumber data, aktivitas produksi, rancangan dan susunan toko, supply chain management, dan manajemen yang efisien, yang mana akan berkontribusi untuk meningkatkan loyalitas pelanggan. Teknik $C R M$ siterapkan pada berbagai bagian berhubungan dengan aktivitas belanja pelanggan, rekomendasi untuk pembelian, pembelian, layanan untuk produk setelah pembelian, dan menawarkan pelayanan untuk mempertahankan pelanggan.

Rigby \& Ledingham (2004) mengidentifikasi lima bagian (segment) siklus CRM dari perspektif bisnis:

\section{Development of Offering}

Bagian ini melibatkan inisiasi dari pemikiran dan pengembangan konsep untuk menarik pelanggan. Pada tahap ini, panel dibuat untuk mengidentifikasi kebutuhan pelanggan dan memutuskan untuk fokus kepada organisasi dalam hubungan dengan area apa yang akan dialamatkan, penawaran dapat dilakukan dan disesuaian dengan kebutuhan biaya untuk mengatasi masalah ini.

\section{Sales (Penjualan)}

Bagian ini melakukan investigasi persoalan penjualan seperti cross-selling dan up- selling. Beberapa fungsi termasuk personalisasi dari proses penjualan, menyediakan kemampuan untuk menyimpan dan melihat pemesanan. Pembuatan purchase order secara otomatis, dan kemampuan untuk menyediakan informasi lengkap dari penjualan merupakan aspek pada segmen ini.

\section{Superior Experience Memuaskan)}

(Pengalaman

Segmen ini melibatkan pembuatan pembelian dan paska penjualan sebagai suatu pengalaman yang memuaskan bagi pelanggan. Pelayanan seperti mengurangi waktu tunggu untuk pembelian, pengiriman, dan pelayanan pelanggan terdapat dalam segmen ini.

\section{Retention and Win Back (Mempertahankan dan Menarik Kembali)}

Segmen ini melibatkan program yang memulai untuk mempertahankan pelanggan atau memenangkan kembali pelanggan. Contohnya pelayanan seperti frequent flier programs atau reward(hadiah) berdasarkan loyalitas pelanggan.

\section{Target and Marketing (Target dan Pemasaran)}

Segmen ini merupakan segmen di mana analisa data utama dibutuhkan. Segmentasi pelanggan sebagai target pemasaran, model perilaku dan personalisasi, strategi promosi, strategi harga untuk menarik pelanggan, dan analisa keuntungan dan kerugian terkait dengan strategi pemasaran berbeda terdapat dalam segmen ini.

\section{Ukuran Tingkat Keberhasilan Customer Relationship Management (CRM)}

Menurut Wijaya \& Darudianto (2009), Ukuran 
tingkat keberhasilan CRM adalah: mengurangi pembuatan laporan, mengurangi biaya dalam melakukan proses bisnis, meningkatkan tingkat kepuasan pelanggan eksternal, meningkatkan produktivitas kerja, meningkatkan tingkat penjualan.

\section{Jenis Customer Relationship Management (CRM)}

Secara garis besar, CRM dapat diklasifikasikan ke dalam 3 jenis, yaitu (Berson, Smith \& Thearling, 2000), yaitu operasional CRM, analitis CRM, dan kolaboratif CRM.

\section{Operasional CRM}

Mencakup otomatisasi yang terintegrasi dari keseluruhan proses bisnis yang terintegrasi, termasuk didalamnya customer touch point dan customer channels dan integrasi front office dan back office. Operasional CRM mengotomatisasi proses bisnis yang berinteraksi secara langsung dengan pelanggannya (Beck \& Summer, 2001). CRM memiliki berbagai aplikasi yang diterapkan dalam penjualan, pemasaran, dan pelayanan yang mendukung proses bisnis. Aplikasi yang mendukung proses bisnis di atas tergolong dalam aplikasi operasional. Aplikasi operasional CRM dibedakan menjadi dua, antara lain: (1) customer facing applications, faktor utama dari aplikasi crm customer facing adalah contact center, Sales Force Automation, dan Field Service. Disebut Customer Facing karena pada kenyataannya, aplikasi ini langsung berhubungan dengan pelanggannya; (2) customer touching applications, faktor utama dari aplikasi CRM Customer-touching applications adalah campaign management, E-commerce dan self service customer support disebut customer touching karena pelanggan berhubungan langsung dengan aplikasi sistem daripada berhubungan dengan perwakilan perusahaan. Strategi operasional CRM ini memfasilitasi tradisional CRM, yang berfokus bagaimana membuat pelayanan, penjualan atau departemen pemasaran lebih efisien dan meningkatkan profibilitas perusahaan dan pelanggan.

\section{Analitis CRM}

Analitis CRM merupakan proses analisis dari datadata yang dihasilkan pada operasional CRM.

\section{Kolaboratif CRM}

Aplikasi pelayanan yang terkolaborasi, seperti email, personalized publishing, e-communities, forum diskusi dan sarana lainnya yang dirancang untuk memfasilitasi interaksi antar pelanggan dan pihak perusahaan. CRM yang terdiri dari ketiga komponen di atas memiliki tujuan secara umum yaitu untuk memaksimumkan keuntungan pelanggan sejalan dengan meningkatkan dan memelihara kepuasan pelanggan.

\section{Keuntungan Customer RelationshipManagement (CRM)}

Menurut (Chatranon, et.al, 2000), keuntungan CRM untuk bisnis dapat dirangkum sebagai berikut: (1) usaha pemasaran yang lebih efektif: hal ini dapat diperoleh karena pelanggan ditetapkan dengan lebih baik. Usaha pemasaran akan berinteraksi langsung dengan harapan dan keinginan pelanggan; (2) interaksi yang lebih efektif dengan pelanggan: Personil pada semua titik kontak bisnis memiliki akses ke database yang akan mengijinkan mereka untuk mengerti dengan lebih baik tiap pelanggan, baik dalam sejarahnya dengan perubahan dan minat mereka; (3) keuntungan jangka panjang dari hubungan yang berkelanjutan: Perusaahaan mendapatkan pelanggan yang loyal. Pelanggan memiliki gambaran yang jelas mengenai produk dan pelayanan (service) yang diinginkan untuk dapat melihat status pemesanan. Masing- masing dari mereka berkomunikasi dengan pesan yang konsisten pada semua titik $\operatorname{kontak}($ contact point), baik customer service, sales people, maupun technical support. Dapat membuat target dan melayani pelanggan dengan suatu cara akan membuat pelanggan untuk kembali. Hal ini merupakan akhir dari pengertian keuntungan jangka panjang untuk perusahaan; (4) berbagi pengetahuan: data pelanggan akan disimpan sebagai dasar pengetahuan (knowledge based) pada suatu database di perusahaan, dan tidak dibatasi hanya pada satu unit bisnis; (5) menghemat biaya: hubungan antara aplikasi front dan back office membuat pelanggan dapat menghemat biaya untuk semua. Proses terotomatisasi dan mengurangi paper-driven system. Selain itu, seluruh siklus layanan (service cycle) dipercepat; (6) tenaga penjualan yang lebih efektif dan efisien: Staff Penjualan memiliki alat yang tepat untuk membantu mereka menghabiskan waktu secara lebih efisien selama proses penjualan, dalam hal menetapkan harga dan konfigurasi, dan metodologi penjualan. Mereka dapat menghabiskan waktu lebih banyak dengan pelanggan dan menjual lebih banyak produk. Bruce Phillip (1999), CFO dari Holphane, telah membuat suatu pernyataan bahwa "Saat ini informasi pesanan dan komersial dan technical support berada ditempat dimana siapapun yang membutuhkan mereka dapat mengakses mereka setiap waktu, waktu persiapan salescall telah terbukti dipotong setengahnya.

\section{Analisis Strenght Weaknesses Opportunities Threats (SWOT)}

Menurut Rangkuti (2001) analisis SWOT adalah identifikasi berbagai faktor secara sistematis untuk merumuskan strategi perusahaan. Analisis ini didasarkan pada logika yang dapat memaksimalkan kekuatan (strengths) dan peluang (opportunities), namun secara bersamaan dapat meminimalkan kelemahan (weakness) dan ancaman (threats).

Penelitian ini menunjukkan bahwa kinerja perusahaan dapat ditentukan oleh faktor internal dan faktor eksternal. Kedua faktor tersebut harus dipertimbangkan dalam analisis SWOT. SWOT adalah singkatan dari lingkungan internal strengths dan weakness serta lingkunga eksternal opportunities dan threats yang dihadapi dunia bisnis. Analisis SWOT membandingkan antara faktor eksternal dengan faktor internal.

\section{Matriks Strenght Weaknesses Opportunities Threats (SWOT)}

MenurutRangkuti(2001),matrikSWOTadalahalatyang digunakan untuk menyusun faktor-faktor strategi perusahaan. Matrik ini menggambarkan bagaimana peluang dan ancaman eksternal yang disesuaikan dengan kekuatan dan kelemahan internal. Matrik ini menghasilkan empat kemungkinan strategi yaitu: (1) strategi Strengths-Opportunities (SO), merupakan strategi perusahaan untuk memaksimalkan kekuatan yang ada untuk memaksimalkankekuatan yang ada untuk meraih peluang secara optimal; (2) strategi Strengths-Threats (ST), merupakan strategi perusahaan untuk meminimalisasi ancaman yang ada dengan memaksimalkan kekuatan yang dimiliki; (3) strategi Weakness-Opportunities (WO), merupakan strategi perusahaan untuk meminimalisasi kelemahan yang dimiliki dengan memanfaatkan peluang yang ada; (4) strategi Weakness-Threats (WT), merupakan strategi perusahaan untuk meminimalisasi ancaman dengan mengurangi kelemahan yang dimiliki. 
Tabel 1 Analisis SWOT

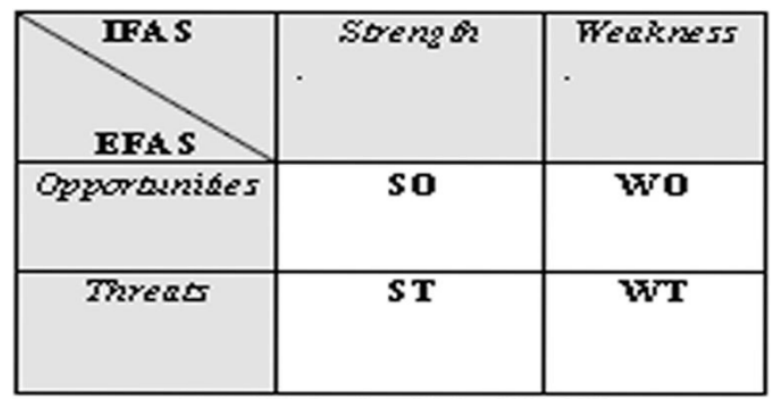

\section{Matrik Faktor Strategi Eksternal (EFAS)}

Setelah faktor strategi eksternal perusahaan diidentifikasi, suatu tabel EFAS dirumuskan untuk menentukan faktor strategis eksternal tersebut dalam rangka opportunities dan threats.

Tabel 2 Faktor Strategi Eksternal

\begin{tabular}{|c|l|l|l|}
\hline $\begin{array}{c}\text { FAKTOR-FAKTOR } \\
\text { STRATEGI EKSTERNAL }\end{array}$ & BOBOT & RATING & $\begin{array}{c}\text { BOBOT X } \\
\text { RATING }\end{array}$ \\
\hline $\begin{array}{c}\text { PELUANG(Opportunities) } \\
\text { ANCAMAN(Threats) }\end{array}$ & & & \\
\hline
\end{tabular}

\section{Matrik Faktor Strategi Internal(IFAS)}

Setelah faktor strategi internal perusahaan di identifikasi, suatu tabel IFAS dirumuskan untuk menentukan faktor strategis internal tersebut dalam rangka strengths dan weakness perusahaan dengan menggunakan cara yang sama diterapkan pada EFAS.

Tabel 3 Faktor Strategi Internal

\begin{tabular}{|c|l|l|c|}
\hline $\begin{array}{c}\text { FAKTOR-FAKTOR STRATEGI } \\
\text { INTERNAL }\end{array}$ & BOBOT & RATING & $\begin{array}{c}\text { BOBOT } \\
\text { X } \\
\text { RATING }\end{array}$ \\
\hline $\begin{array}{c}\text { KEKUATAN(Strength) } \\
\text { KELEMAHAN(Weakness) }\end{array}$ & & & \\
\hline TOTAL & & & \\
\hline
\end{tabular}

\section{Penilaian IFAS dan EFAS}

Setelah dilakukan penilaian IFAS dan EFAS maka dibuatkan diagram untuk menentukan posisis perusahaan, yaitu (1) kuadran 1: merupakan situasi yang sangat menguntungkan. Perusahaan tersebut memiliki peluang dan kekuatan hingga dapat memanfaatkan peluang yang ada melalui kekuatan yang dimiliki; (2) kuadran 2: meskipun menghadapi berbagai ancaman, perusahaan masih memiliki kekuatan dari segi internal. Strategi yang diterapkan adalah menggunakan kekuatan untuk memanfaatkan peluang jangka panjang untuk meminimalkan ancaman yang muncul; (3) kuadran 3: perusahaan menghadapi peluang pasar yang sangat besar, tetapi dilain pihak menghadapi beberapa kelemahan internal. Strategi yang ditetapkan adalah meminimalkan kelemahan internal untuk mencapai peluang yang ada; (4) kuadran 4: merupakan situasi yang tidak menguntungkan. Perusahaan menghadapi beberapa ancaman dan kelemahan internal.

\section{Rapid Application Development (RAD)}

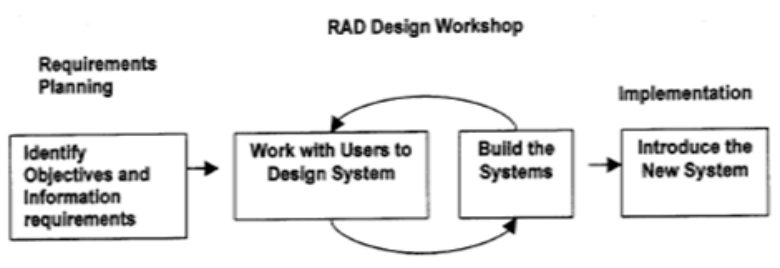

Gambar 1 RAD design workshop

Tahapan Rapid Application Development (RAD) meliputi (Noertjahyana, 2002) rencana kebutuhan, proses desain, dan implementasi.

\section{Rencana Kebutuhan (Requirement Planning)}

Menurut Noertjahyana (2002), pada tahap ini, pengguna dan analis melakukan semacam pertemuan untuk melakukan identifikasi tujuan dari aplikasi atau sistem dan melakukan identifikasi kebutuhan informasi untuk mencapai tujuan. Pada tahap ini hal terpenting adalah adanya keterlibatan dari kedua belah pihak, bukan hanya sekedar persetujuan akan proposal yang sudah dibuat. Untuk lebih jauh lagi, keterlibatan pengguna bukan hanya dari satu tingkatan pada suatu organisasi, melainkan beberapa tingkatan organisasi sehingga informasi yang dibutuhkan untuk masing-masing pengguna dapat terpenuhi dengan baik. Di samping itu, dapat juga melakukan koordinasi dengan pimpinan perusahaan terutama untuk mengembangkan suatu aplikasi e-commerce berbasis web untuk mendapatkan informasi yang lebih detail akan tujuan dari suatu organisasi.

\section{Proses Desain (Design Workshop)}

Pada tahap ini adalah melakukan proses desain dan melakukan perbaikan-perbaikan apabila masih terdapat ketidaksesuaian desain antara pengguna dan analyst. Untuk tahap ini maka keaktifan pengguna yang terlibat sangat menentukan untuk mencapai tujuan, karena pengguna bisa langsung memberikan komentar apabila terdapat ketidaksesuaian pada desain.

Masing-masing pengguna dapat melihat desain yang dibuat melalui komputer dan langsung memberikan komentar. Hal ini sering kali disebut dengan Group Decision Support System (GDSS). Pada beberapa kasus, GDSS ini merupakan suatu langkah yang ideal, karena pengguna dan analyst dapat menyetujui desain yang dibuat untuk kemudian dilanjutkan oleh programmer dalam pembuatan prototipe dari aplikasi yang dimaksud dengan langsung menampilkan kepada pengguna hasilnya dengan cepat.

Pada tahap desain ini membutuhkan waktu beberapa hari akan, tergantung dari besar kecilnya sistem yang dibuat. Pada tahap ini pengguna dapat memberikan tanggapan akan sistem yang dikembangkan untuk selanjutnya dilakukan perbaikan-perbaikan. Dengan demikian proses pengembangan suatu sistem membutuhkan waktu yang cepat.

\section{Implementasi}

Setelah desain dari sistem yang akan dibuat sudah disetujui baik itu oleh pengguna dan analyst, maka pada tahap ini programer mengembangkan desain menjadi suatu program. Setelah program selesai baik itu sebagian maupun secara keseluruhan, maka dilakukan proses pengujian terhadap program tersebut apakah terdapat kesalahan atau tidak sebelum diaplikasikan pada suatu organisasi. Pada saat ini maka pengguna bisa memberikan tanggapan akan sistem yang sudah dibuat serta persetujuan mengenai sistem tersebut. Adapun hal terpenting adalah bahwa keterlibatan pengguna 
sangat diperlukan supaya sistem yang dikembangkan dapat memberikan kepuasan kepada pengguna.

\section{Rumusan Permasalahan}

Setelah diketahui identifikasi masalah yang ada, rumusan masalah di peroleh untuk mengurangi biaya operasional, waktu jadi efisien, dapat di akses kapanpun dan dimanapun, meningkatkan produktivitas kerja, meningkatkan tingkat penjualan, meningkatkan jumlah pelanggan, meningkatkan kepuasan pelanggan. Oleh karena itu dibutuhkan suatu aplikasi web yang dijalankan di platform internet dan mengunakan world wide web yang menyediakan kebutuhan informasi pelanggan melalui Customer Relationship Management berbasis e-commerce tersebut.

\section{METODE PENELITIAN}

Metode yang digunakan meliputi metode analisis dan metode perancangan.

\section{Metode Analisis}

Analisis sistem dilakukan melalui empat tahapan yaitu (1) sistem yang sedang berjalan, yang dilakukan dengan cara observasi wawancara, dan studi pustaka; (2) analisis terhadap temuan survey; (3) identifikasi kebutuhan informasi dari hasil survei yang kemudian menuangkannya dalam tahapan dokumentasi analisis seperti pembuatan flow chart yang menggambarkan prosedur yang sedang berjalan, melakukan proses analisis sistem definisinya, menganalisis class diagram; (4) identifikasi sistem menggunakan bahasa pemrograman PHP dan database menggunakan program mySQL. Sistem harus dapat menerima entri data-data yang berhubungan dengan pelanggan, dan membaca datadata tersebut secara cepat serta menampilkannya. Selain itu, analisis juga dilakukan dengan evaluasi sistem melalui SWOT untuk mengetahui sejauh mana kekuatan, kelemahan, kesempatan, dan ancaman yang dialami perusahaan.

\section{Metode Perancangan}

Pengembangan aplikasi web dilakukan dengan beberapa tahapan yang menggunakan prinsip object oriented, yaitu dengan (1) pembuatan model aplikasi, di mana akan dilakukan dengan notasi UML. Model sistem yang digambarkan antara lain class diagram, dan use case diagram yang berbasiskan teori Mahiassen (2000) serta activity diagram dan sequence diagram yang berbasiskan teori Bennet (2005); (2) melakukan pengembangan Customer Relationship Management berbasis sistem e-commerce. Sistem ini menggunakan bahasa pemograman PHP dan database MySQL.

\section{HASIL DAN PEMBAHASAN}

\section{Fitur dalam Customer Relationship Management Berbasis E-commerce bagi Calon Member}

Rancangan situs web Customer Relationship Management berbasis sistem e-commerce yang dibuat, dapat memberikan kemudahan bagi calon member/pelanggan dalam bentuk antara lain: (1) melakukan proses pendaftaran secara online melalui fitur registrasi; (2) mengetahui sejarah PT Dwisanjaya Abadi Mukti secara online melalui fitur Tentang Kami; (3) mengetahui berita terbaru secara online melalui fitur Promo; (4) mengetahui berita terbaru secara online melalui fitur Daftar Harga; (5) mengetahui berita terbaru secara online melalui fitur Cara Pembayaran; (6) mengetahui berita terbaru secara online melalui fitur Kontak Kami; (7) mengetahui pertanyaan-pertanyaan yang sering diajukan customer kepada perusahaan secara online melalui fitur Frequently Asked Questions.

Selain dalam bentuk seperti fasilitas yang disediakan bagi calon member, rancangan situs web Customer Relationship Management berbasis sistem E-commerce tersebut juga dapat memberikan kemudahaan bagi member/ pelanggan dengan beberapa kemudahan tambahan lainnya seperti: (1) mengetahui berita terbaru secara online melalui fitur Berita; (2) member dapat melihat sejarah pembelian yang pernah dilakukan oleh member secara online melalui fitur Purchase History; (3) member memiliki keranjang belanja, sehingga jika member ingin memesan produk baik dalam jumlah yang sedikit maupun banyak, maka pesanan tersebut akan secara otomatis masuk ke dalam keranjang belanja member melalui fitur shopping cart. Fitur ini berfungsi agar member dapat menganalisis kembali pemesanannya sebelum diproses untuk masuk ke database pemesanan; (4) member dapat memberitakan pertanyaan maupun saran secara online melalui fitur Question and Comment; (5) member dapat mengecek pemberitahuan atau informasi penting dari admin secara online melalui fitur Notice; (6) jka member memerlukan bantuan, ia dapat melakukan chatting dengan admin divisi customer service melalui fitur Yahoo Messenger; (7) member dapat melihat promo-promo yang disediakan perusahaan secara online melalui fitur Promo; (8) member dapat mengisi kuisioner secara online melalui fitur Kuesioner sehingga lebih mudah dan cepat; (9) member dapat berpartisipasi dalam pengisian polling mengenai apa yang diminati oleh sesama member sesuai dengan topik yang ditentukan oleh admin.

\section{Fitur dalam Customer Relationship Management Berbasis Sistem E-commerce Bagi Admin}

Selain dapat memberi kemudahan kepada member, pengembangan Customer Relationship Management berbasis sistem e-commerce yang dibangun pada sistem yang baru ini juga memberikan beberapa keuntungan bagi admin staf penjualan dan pemasaran serta staf akuntansi dan keuangan. Keuntungan bagi admin staf penjualan dan pemasaran, yaitu: (1) dapat melihat pemesanan produk-produk yang telah terjadi dengan cepat secara online melalui fitur order; (2) dapat melihat purchase order secara online dengan cepat melalui fitur order; (3) dapat berinteraksi tanya jawab dengan member melalui fitur question and comment; (4) dapat melakukan chatting dengan member secara cepat melalui fitur yahoo messenger; (5) dapat mengecek pemberitahuan atau informasi penting dari admin dan mengirim informasi tersebut secara online melalui fitur notice; (6) dapat memberikan polling kepada member dan melihat hasilnya dengan cepat secara online melalui fitur polling; (7) menginput pertanyaan kuisioner secara online melalui fitur kuisioner; (8) mengetahui pertanyaan-pertanyaan yang sering diajukan customer kepada perusahaan dan menginput pertanyaan baru berserta jawabannya secara online melalui fitur Frequently Asked Questions.

Sementara itu, keutungan bagi admin staf akutansi dan keuangan, yaitu: (1) dapat mengecek purchase order secara online yang telah dibuat oleh customer; (2) menginput status pembayaran dan langsung menyimpan data-data pembayaran kedalam database payment secara online melalui fitur order.

\section{Fitur Customer Relationship Management Berbasis Sistem E-commerce}

Fitur-fitur yang termasuk dalam jenis collaborative 
Customer Relationship Management adalah Question and Comment merupakan fitur yang memungkinkan member secara pribadi mengajukan pertanyaan maupun saran kepada customer service.

Fitur-fitur yang termasuk dalam jenis operational Customer Relationship Management adalah: (1) Frequently Asked Questions yang menyediakan sarana untuk melihat pertanyaan-pertanyaan yang umumnya sering menjadi pertanyaan bagi pelanggan dan menampilkan jawabannya; (2) berita yang menampilkan berita terbaru; (3) Shopping Cart: Fitur ini berfungsi sebagai keranjang belanja, sehingga jika member ingin memesan produk baik dalam jumlah yang sedikit maupun banyak, maka pesanan tersebut akan secara otomatis masuk ke dalam keranjang belanja member melalui fitur shopping cart. Fitur ini berfungsi agar member dapat menganalisis kembali pemesanannya sebelum diproses untuk masuk ke database pemesanan; (4) Purchase History: member dapat melihat data-data transaksi pembelian yang telah dilakukannya; (5) Notice: notice terdapat pada member maupun staf penjualan dan pemasaran. Notice ini berisi pemberitahuan atau informasi penting. Notice ini juga menjadi suatu wadah interaksi antara member dan staf penjualan dan pemasaran mengenai pemesanan yang dilakukan member. Pada member, notice ini berfungsi sebagai pemberitahuan ke member.

Fitur-fitur yang termasuk dalam jenis analitik Customer Relationship Management adalah: (1) kuesioner yang menyediakan sarana bagi member untuk menjawab pertanyaan-pertanyaan yang diajukan sebagai feedback bagi perusahaan; (2) Polling merupakan sarana untuk mengetahui persentase kecenderungan pemintaan dari customer terhadap suatu masalah atau topik tertentu.

\section{Class Diagram}

\section{Class Diagram Front End}

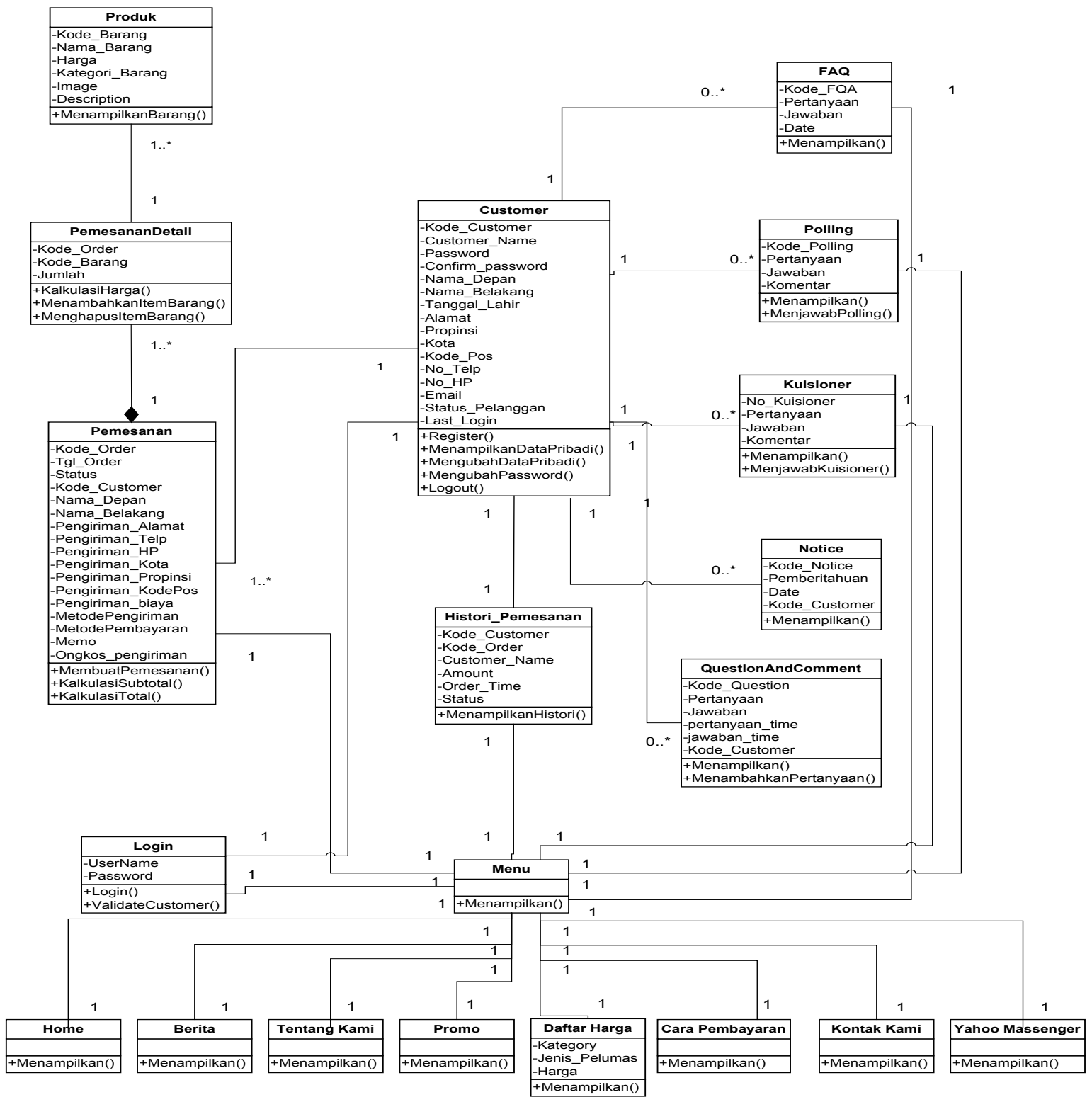

Gambar 2 Class diagram front end 


\section{Class Diagram Back End}

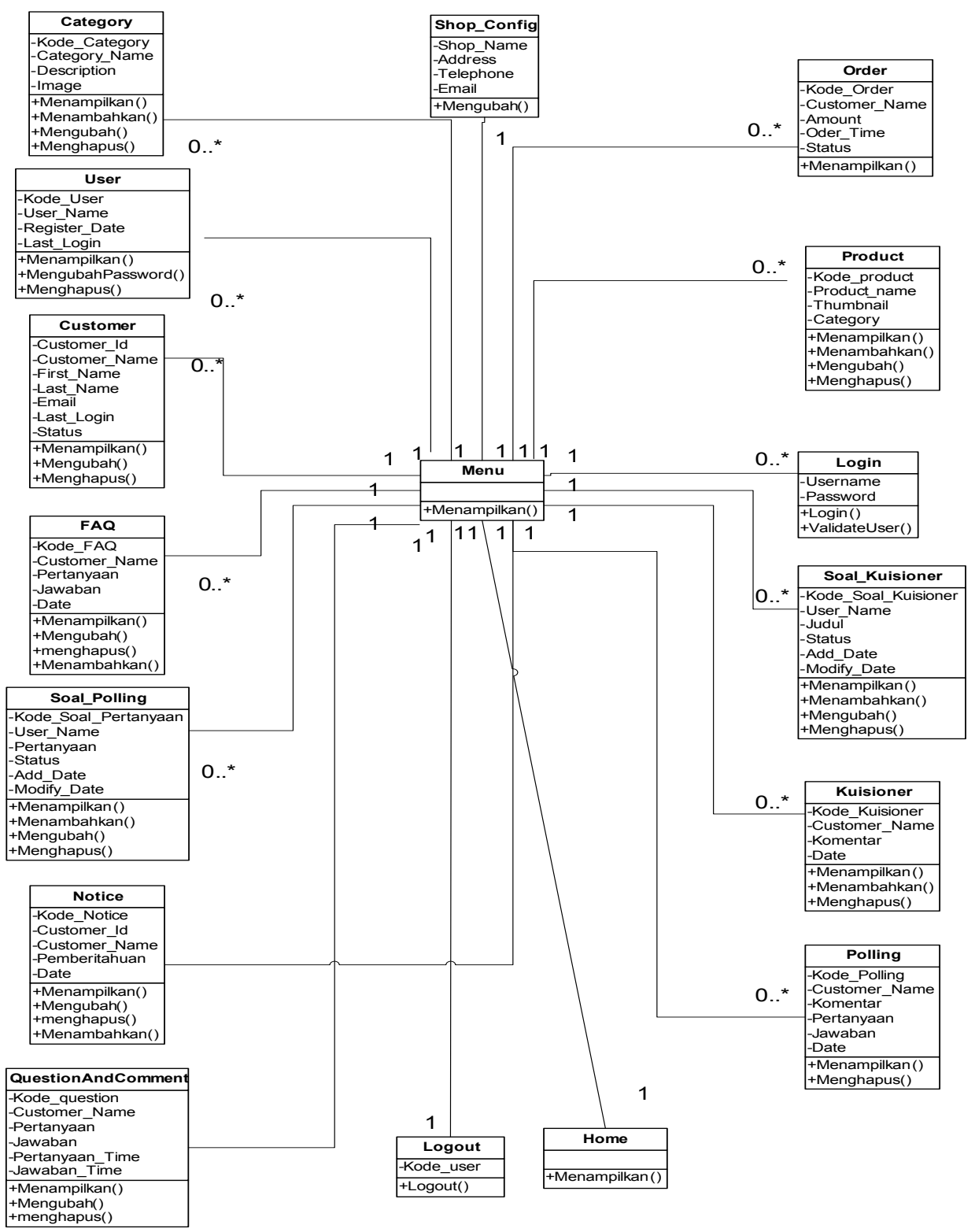

Gambar 3 Class diagram back end

\section{Actor Front End}

Tabel 1 Actor Table Front End

\begin{tabular}{l} 
Use Case \\
\hline Mendaftar customer \\
\hline Melihat produk \\
\hline Memesan produk \\
\hline Melihat sejarah pemesanan \\
\hline Melihat data pribadi \\
\hline Mengubah data pribadi \\
\hline Mengubah password
\end{tabular}

\begin{tabular}{l}
\hline Melihat notice \\
\hline Mengisi question and comment \\
\hline Melihat FAQ \\
\hline Mengisi polling \\
\hline Mengisi kuisioner \\
\hline Melihat berita \\
\hline Melihat tentang kami \\
\hline Melihat promo \\
\hline Melihat daftar harga \\
\hline Melihat cara pembayaran \\
\hline Melihat kontak kami \\
\hline
\end{tabular}


Pada gambar-gambar di atas dilihat hubungan antara actor dan use case bagian Front End yang ada dalam sistem di perusahaan PT. Dwisanjaya Abadi Mukti. Dalam sistem di perusahaan ini terdapat 1 buah actor antara lain customer. Customer perusahaan PT. Dwisanjaya Abadi Mukti terlibat dalam use case mendaftar customer, memesan produk, melihat produk, melihat sejarah pemesanan, melihat data pribadi, mengubah data pribadi, mengubah password, melihat notice, mengisi question and comment, melihat $F A Q$, mengisi polling, mengisi kuisioner, melihat berita, melihat tentang kami, melihat promo, melihat daftar harga, melihat cara pembayaran, melihat kontak kami.

\section{Actor Back End}

Tabel 2 Actor table back end

\begin{tabular}{|c|c|c|}
\hline Use Case & $\begin{array}{l}\text { Staf } \\
\text { penjualan } \\
\text { dan } \\
\text { pemasaran }\end{array}$ & $\begin{array}{l}\text { Staf akutansi dan } \\
\text { keuangan }\end{array}$ \\
\hline \multicolumn{3}{|l|}{ Mengelola category } \\
\hline \multicolumn{3}{|l|}{ Mengelola product } \\
\hline \multicolumn{3}{|l|}{ Mengelola pemesanan } \\
\hline \multicolumn{3}{|l|}{$\begin{array}{l}\text { Mengubah status } \\
\text { pemesanan }\end{array}$} \\
\hline \multicolumn{3}{|l|}{ Mengelola shop config } \\
\hline \multicolumn{3}{|l|}{ Mengelola user } \\
\hline \multicolumn{3}{|l|}{ Mengelola customer } \\
\hline \multicolumn{3}{|l|}{ Mengubah status customer } \\
\hline \multicolumn{3}{|l|}{ Mengelola notice } \\
\hline \multicolumn{3}{|l|}{$\begin{array}{l}\text { Mengelola question and } \\
\text { comment }\end{array}$} \\
\hline \multicolumn{3}{|l|}{ Mengelola $F A Q$} \\
\hline \multicolumn{3}{|l|}{ Mengelola soal polling } \\
\hline \multicolumn{3}{|l|}{ Mengelola polling } \\
\hline \multicolumn{3}{|l|}{ Mengelola soal kuisioner } \\
\hline \multicolumn{3}{|l|}{ Mengelola kuisioner } \\
\hline \multicolumn{3}{|l|}{ Mengubah berita } \\
\hline \multicolumn{3}{|l|}{ Mengubah tentang kami } \\
\hline \multicolumn{3}{|l|}{ Mengubah promo } \\
\hline $\begin{array}{l}\text { Mengubah cara } \\
\text { pembayaran }\end{array}$ & & \\
\hline
\end{tabular}

Mengubah kontak kami

Pada gambar di atas dilihat hubungan antara actor dan use case bagian Back End yang ada dalam sistem di perusahaan PT Dwisanjaya Abadi Mukti. Dalam sistem di perusahaan ini terdapat 2 buah actor antara lain (staf penjualan dan pemasaran) dan (staf akuntansi dan keuangan). Staf penjualan dan pemasaran perusahaan PT Dwisanjaya Abadi Mukti terlibat dalam use case mengelola category, mengelola product, mengelola pemesanan, mengubah status pemesanan, mengelola shop config, mengelola user, mengelola customer, mengubah status customer, mengelola notice, mengelola question and comment, mengelola $F A Q$, mengelola soal polling, mengelola polling, mengelola soal kuisioner, mengelola kuisioner, mengubah berita, mengubah tentang kami, mengubah promo, mengubah cara pembayaran, mengubah kontak kami. Staf akuntansi dan keuangan berhubungan dengan use case mengubah status pemesanan.

\section{Use Case Diagram Front End}

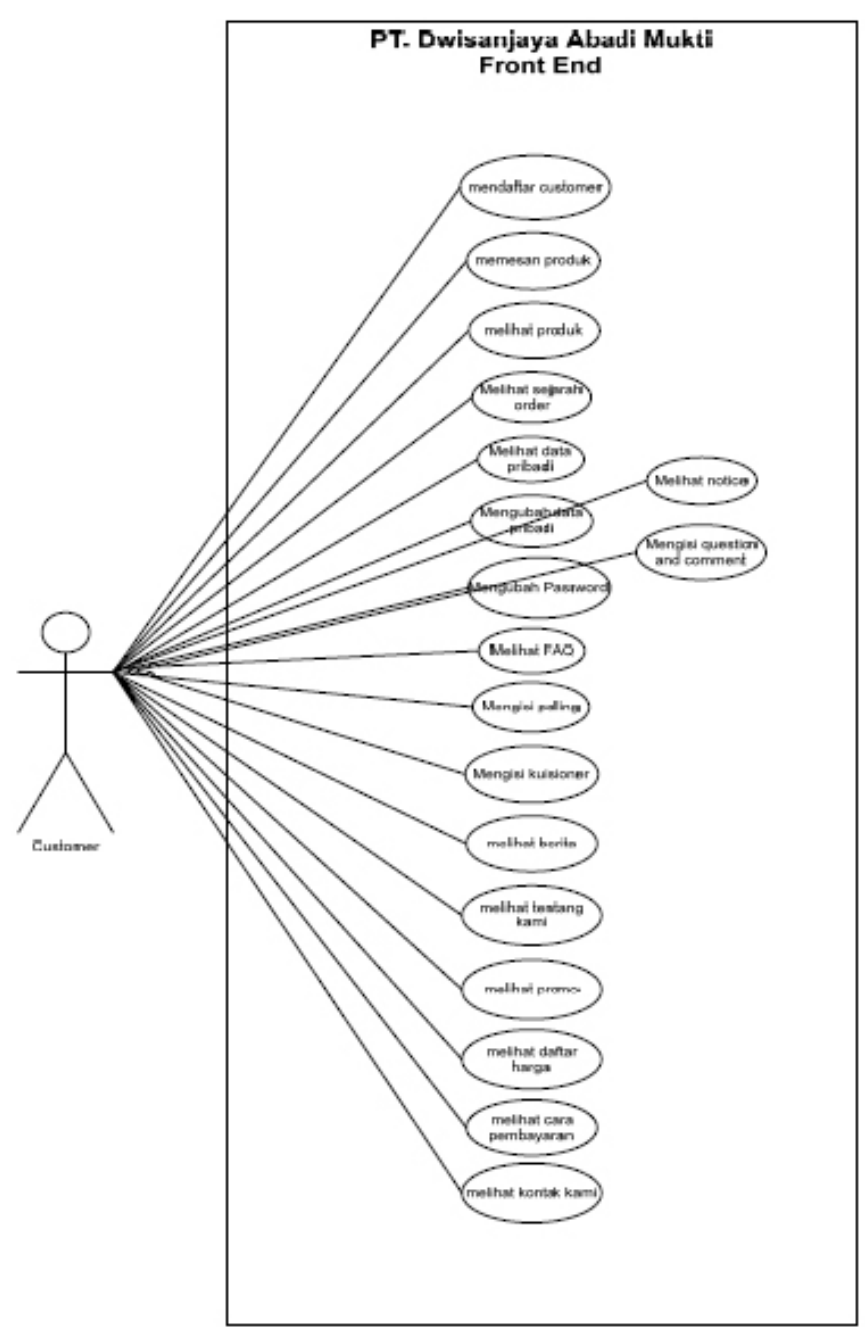

Gambar 4 Use case diagram front end

\section{SIMPULAN}

Simpulan dari penelitian ini yaitu: (1) pengembangkan Customer Relationship Management berbasis sistem e-commerce yang terbagi dua bagian yaitu front office dan back office, untuk mengatasi persoalan pembelian dan pelayanan kepada pelanggan yang masih manual; (2) pengguna dapat memperoleh informasi yang diinginkan dengan cepat, untuk memperoleh pelanggan baru, meningkatkan hubungan dengan pelanggan, mempertahankan pelanggan; (3) mengurangi biaya operasional, waktu jadi efisien, dapat diakses kapanpun dan dimanapun, meningkatkan produktivitas kerja, meningkatkan penjualan, meningkatkan jumlah pelanggan, meningkatkan kepuasan pelanggan.

\section{DAFTAR PUSTAKA}

Beck, B., \& Summer, J. (2001). Data warehousing horizons, CRM: not just operational and collaborative. Retrieved from http:// www.dmreview.com/master.cfm? $N a v I D=198 \& E d I D=3956$

Bennet, S., McRobb, S., \& Former, R. (2005). Object oriented system analysis and design using UML (3rd ed.). New York: McGraw-Hill.

Berson, A., Smith, S., \& Thearling, K. (2000). Building data mining applications for CRM. USA: The McGraw-Hill Companies, Inc.

Chaffey, D. (2002). E- Business and commerce management. New 
Jersey: Prentice Hall International, Inc.

Chatranon, A., Chen, J. C. H., Chong, P. P., \& Chen, Y.S. (2001) Customer relationship management (CRM) and e-commerce. Proceedings to the first international conference on electronic business, Hong Kong, China, (2001) 19-21.

Chaudhury, A., \& Kuilboer, J. (2002). E-business and e-commerce infrastructure: technology suporrting the e-business initiative. The McGraw-Hill, Inc.

Irawan, H. (2002). 10 Prinsip Kepuasan Pelanggan. Jakarta: Elex Media Komputindo.

Kotler, P., \& Keller, K. L. (2006). Marketing management (11th ed.). New Jersey: Pearson Education, Inc.

Mane, S., Desikan, P., \& Srivastava, J. (2005). From clicks to bricks: CRM lessons from e-commerce. Retrieved on October 12, 2005, from http://www.cs.umn.edu/tech_reports_upload/tr2005/05033.pdf

Mathiassen, L., Madsen, A. M., Nielsen, P. A., \& Stage, J. (2000). Object oriented analysis \& design. Denmark: Marko Publishing Aps.

Noertjahyana, A. (2002). Studi Analisis Rapid Application Developement sebagai salah satu alternatif metode pengembangan perangkat lunak. Jurnal Informatika vol. 3, No. 2.(2002).74-79.

Rangkuti, F. (2001). Analisis SWOT teknik membedah kasus bisnisreorientasi konsep perencanaan strategis untuk menghadapi abad 21 (8th ed.). Jakarta: Gramedia Pustaka Utama.

Rangkuti, F. (2002). Measuring customer satisfaction. Jakarta: Gramedia Pustaka Utama.

Rayport, J. F., \& Jaworski, B. J. (2004). Introduction to e-commerce (2nd ed.). New York: The McGraw-Hill, Inc.

Rigby, D. and Ledingham, D. (2004) "CRM Done Right”, Harvard Business Review, Vol. 82 No. 11

Schiffman, L., Bednall, D., O $\mid$ Cass, A., Paladino, A. \& Kanuk, L. (2005). Consumer behavior (3rd ed.). Australia: Pearson Education.

Wijaya, S. F., \& Darudianto, S. (2009). ERP \& solusi bisnis. Yogyakarta: Graha Ilmu.

\section{APPENDIX}

\section{Use Case Diagram Back End}

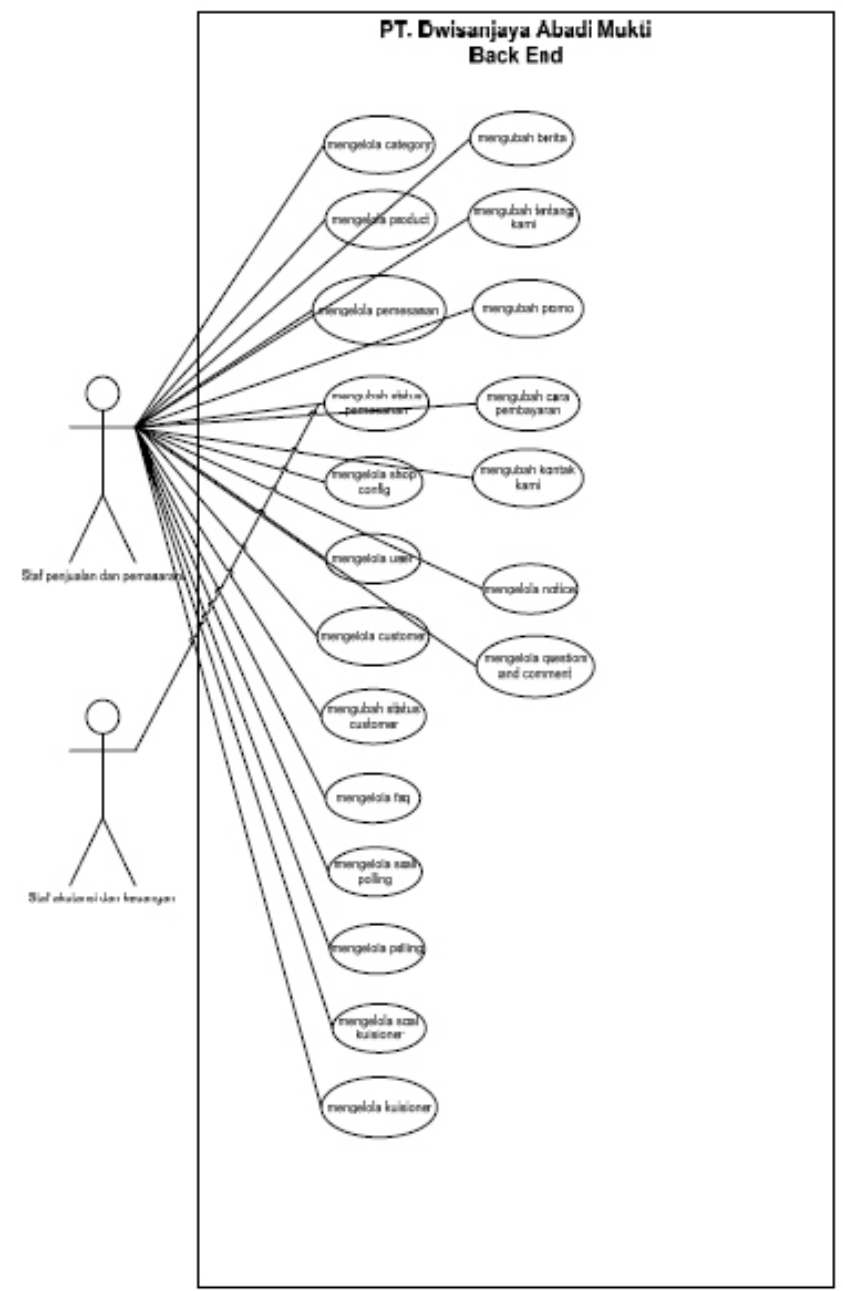

Gambar 5 Use case diagram back end 